\title{
Remote Sensing and Geographic Information System for Fault Segments Mapping a Study from Taiz Area, Yemen
}

\author{
Anwar Abdullah, Shawki Nassr, and Abdoh Ghaleeb \\ Geology Department, Faculty of Applied Science, Taiz University, Taiz, Yemen \\ Correspondence should be addressed to Anwar Abdullah; alhrani@gmail.com
}

Received 13 June 2013; Revised 19 September 2013; Accepted 19 September 2013

Academic Editor: Karoly Nemeth

Copyright (C) 2013 Anwar Abdullah et al. This is an open access article distributed under the Creative Commons Attribution License, which permits unrestricted use, distribution, and reproduction in any medium, provided the original work is properly cited.

GIS and remote sensing data for allowing detection of structural features, such as faults, offer opportunities for improving mapping and identifying the areas that are likely to be locations of faulting areas. Landsat ETM-7 satellite data images were used and band-5 was found as the most suitable band for lineament delineation, based on the ability to identify geological features. Four contributing factors, namely, drainage patterns, faults (previously mapped), lineaments, and lithological contacts layers, were parameters used in this study to produce a fault potential prediction map using the overlay model techniques. The potential map (fault susceptibility map) classifies the study area into five potential zones, namely, very low, low, moderate, high, and very high potential. The areas covered by moderate to the highest potential zones were considered as fault segments (fault lines) in the area. The comparison of the potential map and the published fault map by using GIS matching techniques shows that 75 fault segments (fault lines) in the potential map were not properly identified in the study area. The correlation between fault segments and faults data collected from field work stations shows that there were 39 fault segments which may represent new faults in the area being identified. The presence of these faults is not known from the literature; this leads to updating and revising of existing geological map of the study area.

\section{Introduction}

Faults are weakness zones in the brittle part of the lithosphere, along which movement can take place in response to induced stresses. When faults undergo displacement, depending on geological and structural conditions, strain markers can be formed on the fault surface [1]. The presence of faults in any area is based on displacement of rock layers. But also, most of faults are represented by some geological features such as drainage patterns, lineaments (linear features), and lithological contacts between rock units within the rocks of the area. The presence of faults may be indicated by these geological features (factors).

The term lineament was first introduced by $[2,3]$ who recognized the existence of linear geomorphic features and interpreted them as surface expressions of zones of weakness or structural displacement of the earth's crust. Lineaments are linear features on the Earth's surface, usually related to the subsurface phenomena. Generally, lineaments are related to large fractures and faults where their orientation and number give an idea of fracture pattern of rocks [4]. In the recent years, the lineaments have been defined as natural crustal structures that may represent a zone of structural weakness [5].

The drainage system, which develops in an area, is strictly dependent on the slope, the nature, and attitude of bedrock and on the regional and local fracture pattern [6]. Most stream networks are adapted to regional slope and geological structures, picking out the main fractures in the underlying rocks [7].

The contact between two lithologies can also appear as a linear feature. This contact may appear as a change in drainage pattern across the structural features [8] or the two units may have different spectral properties [9].

Based on the definitions of lineaments, drainage patterns (including pattern the length, spatial distributions), and the lithological contacts between different rock types, the faults could be mapped in the study area. These geological features mostly resemble a fault lines in the area. The most important features in the area are the presence of drainage lines patterns 
and fractures. Lineaments, drainages, lithological contacts, and previous fault lines data are important data and used in this research for fault segments mapping using GIS technique.

With the advent of remote sensing and computer technology in the geosciences, geological investigation and interpretation have entered a new era. Remote sensing technology is very efficient for collecting data. Computer technology, such as computer-based geographic information system (GIS), supplies a different method for data storage, integration, analysis, and display. The combination of remote sensing and GIS provides an optimum system for various geological investigations such as fault mapping [10].

Several studies have been carried out to enhance geological knowledge and revise existing geological maps by using optical remotely sensed data and discovered new faults that were previously unmapped [11-16]. Furthermore, authors in $[17,18]$ conclude by suggesting that satellite images and/or geographic information systems (GIS) are useful for tectonic mapping and identifying previously unmapped faults.

The benefit of integrating different data and techniques in structural features such as faults identification and analysis made possible using remote sensing and GIS techniques is the ability to identify faults based on their characteristics. Creation and classification of various types of geological features can be carried based on the purpose of the study. Once the identification, preparation, and processes are complete, geographic information systems (GIS) functionality, such as vector and raster spatial analysis and overlay, can be employed for structural mapping and analysis using powerful software programs [19].

Generally, Yemen is located in the southwestern part of Arabian Peninsula, and it is affected by an active rifting zone of the Gulf of Eden and the Red Sea opening. This active (rifting) zone can cause the reactivation of the old fault systems and may create new faulting lines in the area. The active faults (such as, rock mass movements or sliding on the fault planes and bedrock lithologies cracking) may cause severe damages in some places, especially in urban or settlements areas. For example, bedrock cracking and rock mass sliding happened in the 2003 and 2010 in some places in Taiz city caused severe damages, and many houses, roads, and other infrastructures were destroyed.

The previous works (data) such as geological and structural maps are very old data, showing a few of fault lines in the study area. For this purpose, mapping of faults may lead to updating these data. In this paper, the using of remote sensing (data processing) and GIS (modeling) techniques could be helpful tools for mapping of faults, where the different geological features (factors) are taken in the considerations. The results of the work could be considered from the government or the people before or during the different construction projects, to increase the safety, especially in the urban areas.

The purpose of this study was to test the integration between remote sensing and geographic information system (GIS) for detecting the fault segments (fault lines) over the study area and to investigate the ability of this method in giving real results compared to the previous data with respect to the ground truth (field work).
The study area located in the southwest of Yemen has an area of $176 \mathrm{~km}^{2}$. It includes Taiz city and extends between Rubayi and Al-Hawban areas (Figure 1).

According to GSY [20] classification, the rocks in the study area are divided into two groups as follows.

(1) Tertiary (granite body intrusive).

(2) Tertiary (volcanic rocks such as basalt, rhyolite, dacite, ignimbrite, and ashflow deposits).

The geological map of the study area (Figure 2) was digitized from the geological sheet map of Taiz with scale $1: 250,000$.

\section{Materials and Methods}

Various data were used for fault segment susceptibility mapping (potential fault zones mapping) in the study area. Various image processing and enhancement techniques were applied on different remote sensing data including the Landsat ETM-7 (Enhanced Thematic Mapper) satellite images and SRTM (The Shuttle Radar Topography Mission) to get maximum information by using different approaches of extraction methods. The other data used in this study were topographic maps, geological maps, and field data.

During conducting this study, many different software packages were used since there was no single software that would process all steps in the analyses. Therefore, the diverse software used for the analysis in the current study is PCI Geomatica (version 9.1), ERDAS (version 8.4), and Ilwis software (version 3.3).

2.1. Data Processing. According to this paper the linear features delineation was based on decision of the most appropriate data, such as drainage patterns, lineament, fault (previously mapped), and lithological contact layers for mapping of fault segments using GIS. Many of researchers such as [21-26] have utilized lineaments, drainage patterns, faults, and lithology factors as important factors to measure and map the susceptibility of geological hazard. Therefore, the input attributes of the structural features of an area should be studied as a first consideration.

The previous data about the study area including geological, structural, and topographic maps are digitized. To prepare these maps, first, the maps are converted into a digital format by using the scanner. There are some data which were extracted from data in digital formats, such as Landsat ETM satellite images and SRTM.

Generally, four digital layers (maps) such as drainage patterns, fault (previously mapped), lineament, and lithological contact were prepared and converted into secondary data such as drainage buffer, fault buffer, lineament buffer, and lithological contacts buffer layers.

These layers were converted into slicing layers with five classes. Each class was determined as $30 \mathrm{~m}$. This is because these layers were generated from different data (ETM, SRTM, and previous maps) with different spatial resolutions and scales. Due to this, these layers should be enhanced and resampled (rescaled) to be suitable in resolution for GIS 


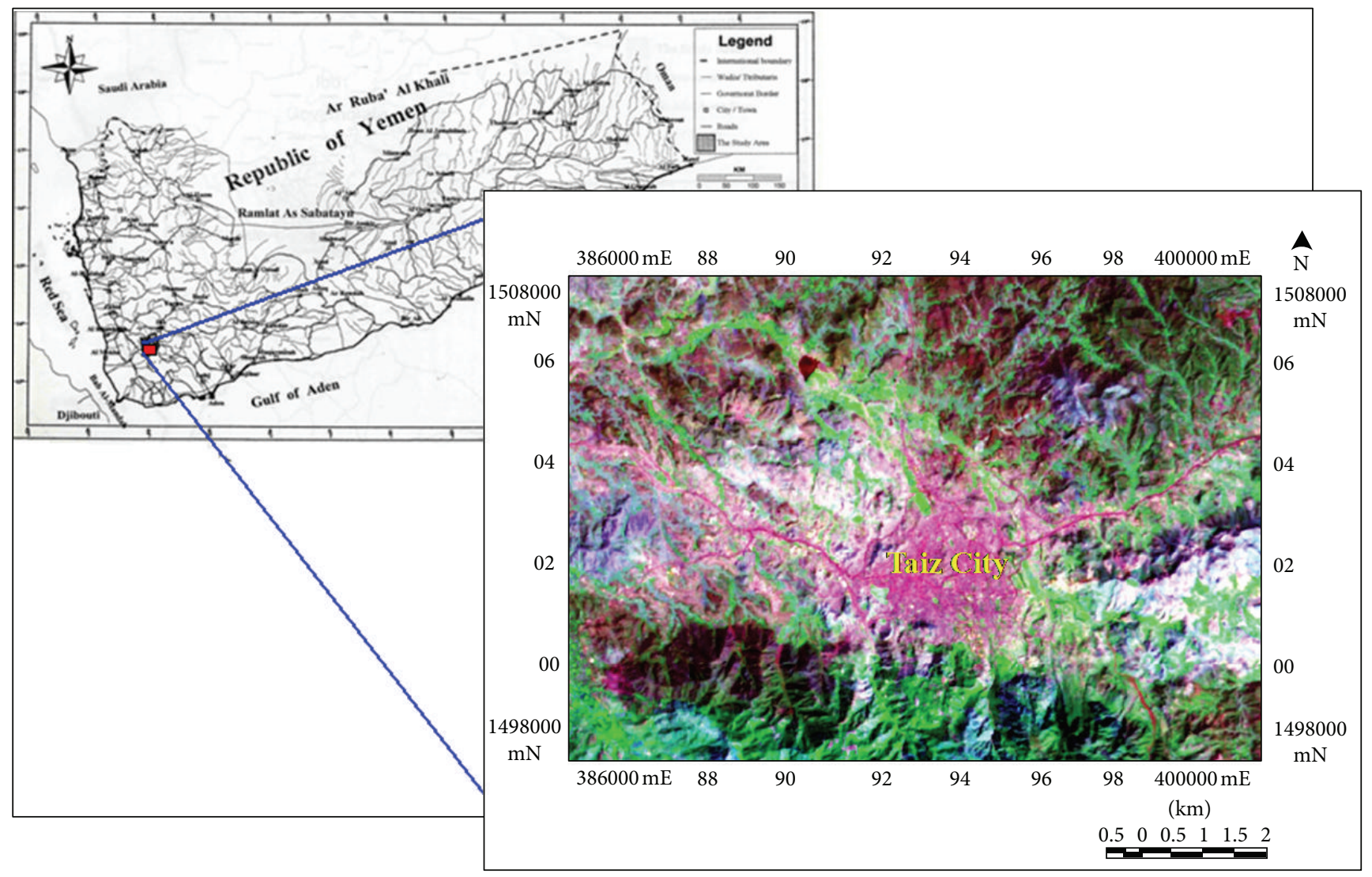

FIGURE 1: Location of the study area.

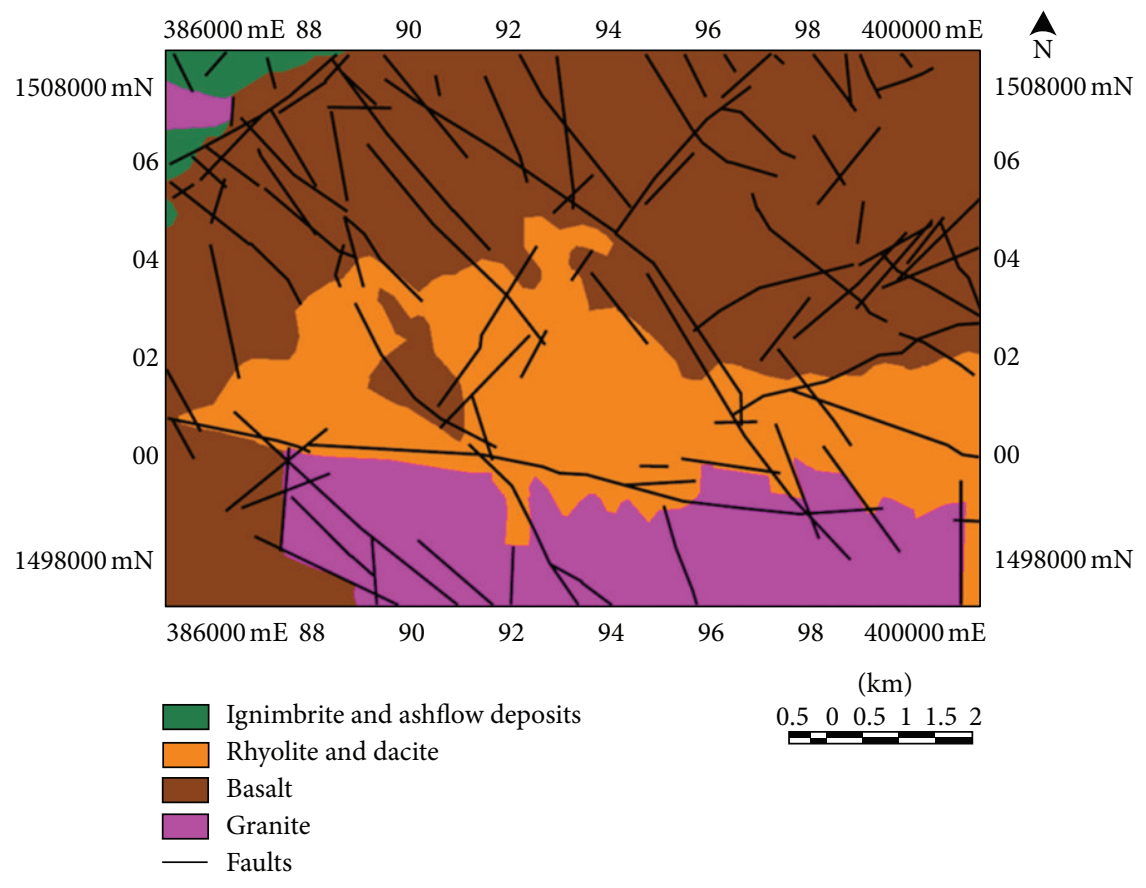

FIGURE 2: Geological map of the study area [20]. 


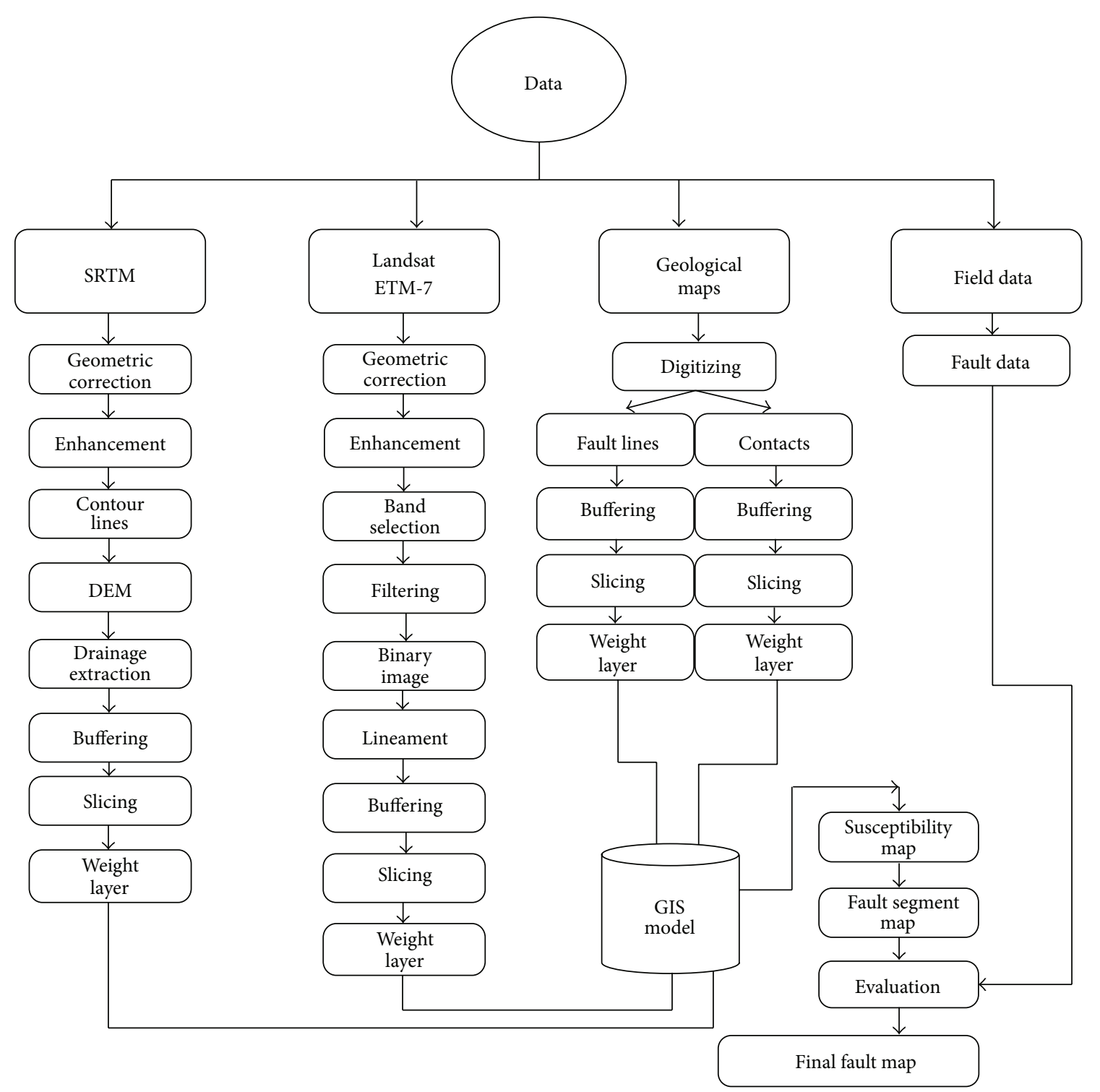

Figure 3: Chart of the methodology in this study.

model. The resolution was selected as $30 \mathrm{~m}$ for this process based on the ability of satellite image of $30 \mathrm{~m}$ spatial resolution to identify the geological features in the area. Then, slicing layers were converted into weight layers (thematic layers). These procedures are illustrated in Figure 3.

Arbitrary classifications are still common; however, the main classification approaches are ranking, natural breaks, equal interval classes, equal area classes, and mean value and standard deviation intervals [25, 27-29]. Hence, the classification determines the spatial distribution of buffering zones or susceptibility (classifying susceptibility) based on equal area classes.

Classes (five classes of each weight layer) and their weight values are given in Table 1. Each class has a weight to express the contribution to the occurrence of fault segments. The weight value was assigned to be between 1 to 5 (Table 1 ).
TABle 1: Parameters and the weight values are given to different factors in the study area.

\begin{tabular}{lc}
\hline Classes & Weight value \\
\hline$<30 \mathrm{~m}$ & 5 \\
$30-60 \mathrm{~m}$ & 4 \\
$60-90 \mathrm{~m}$ & 3 \\
$90-120 \mathrm{~m}$ & 2 \\
$>120 \mathrm{~m}$ & 1 \\
\hline
\end{tabular}

These weight layers (maps) were input into GIS model. The resultant map (susceptibility map) was classified into different zones, very low, low, moderate, high, and very high fault susceptibility zones or equal area classes using ranking approach. 


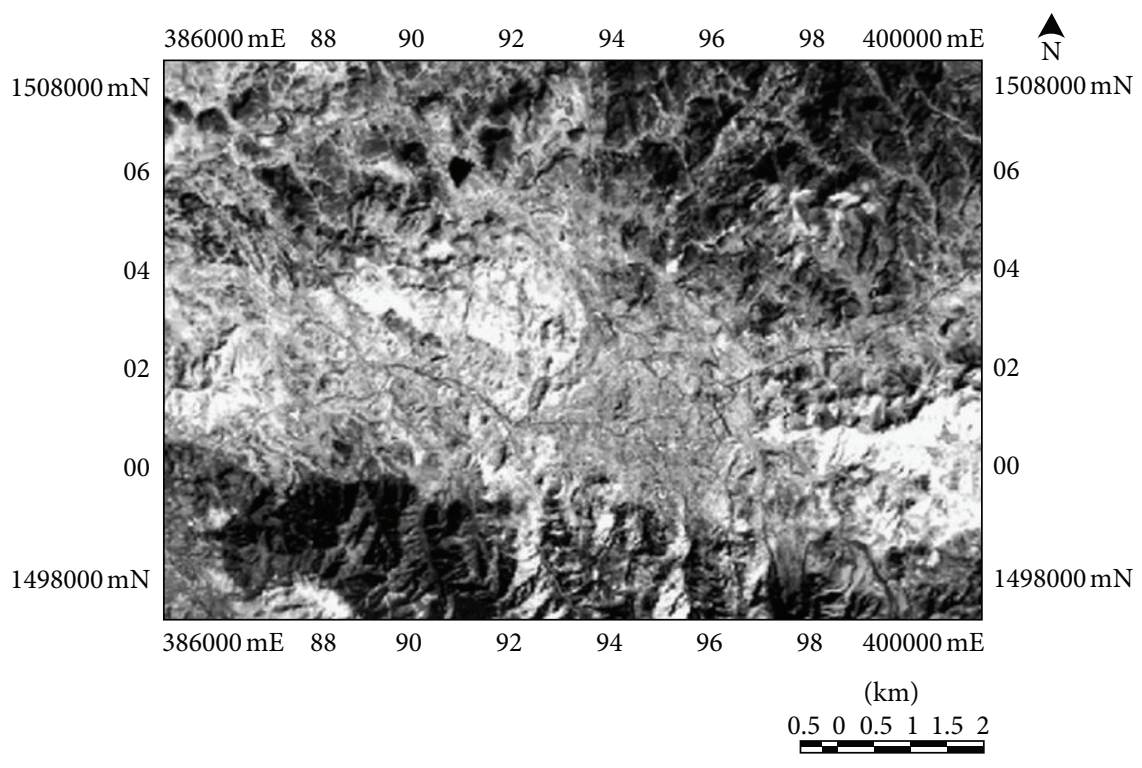

FIgURE 4: Original band-5 of Landsat ETM-7.

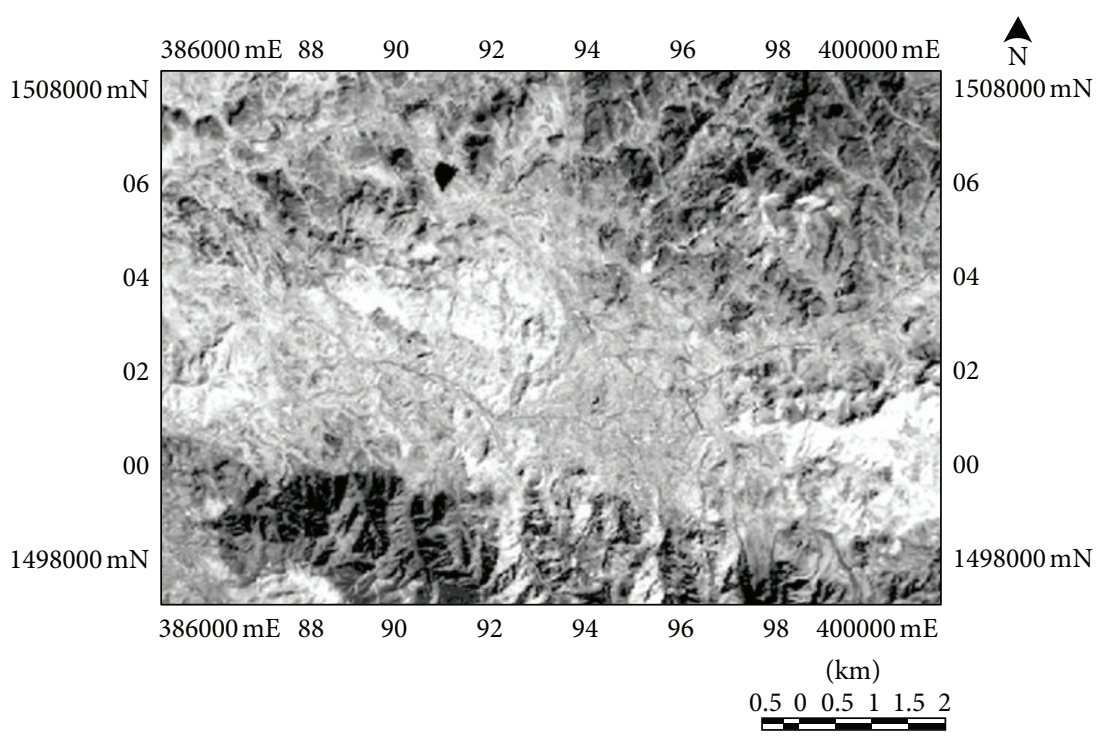

FIGURE 5: Band-5 of Landsat ETM-7 after contrast enhancement.

2.1.1. Lineament Factor. Lineaments are related to large structural fractures [4] and it may represent zones of weakness [22]. Also, the presence of tectonic structures such as linear features could be important factor in geological hazard occurrences [30,31].

Filtering is useful in image enhancement. An edgeenhancing filter can be used to highlight any changes of gradient within the image features, such as structural lines [17, 28, 32-37]. They generated lineament maps and determined several significant structural features.

In the recent years, the lineaments have been defined as natural crustal structures that may represent a zone of structural weakness [38]. Landsat ETM-7 satellite data were used and the first step was to select the band that should be used for lineament extraction [39]. Visual inspection of the individual bands was carried out, based on the ability to identify features, and band-5 (1.55-1.75 $\mu \mathrm{m})$ (SWIR) was selected as shown in Figure 4. And it was stretched linearly to output range from 0 to 255 (Figure 5), because it is the least affected band by the scattering, through the travel path of the long wavelength in the atmosphere. Therefore, it shows a good contrast and better display of geological features compared to other bands.

The second step was to select the filter type. For this purpose, different types of filters are tested such as 3 by 3 sobel kernel filter, 5 by 5 edge kernel filter, and 7 by 7 edge kernel filter. The 5 by 5 and 7 by 7 edge enhancement filters give thicker and less linear areas after threshold application; sobel results in thinner and more linear zones that give the best result compared with other two filters. 


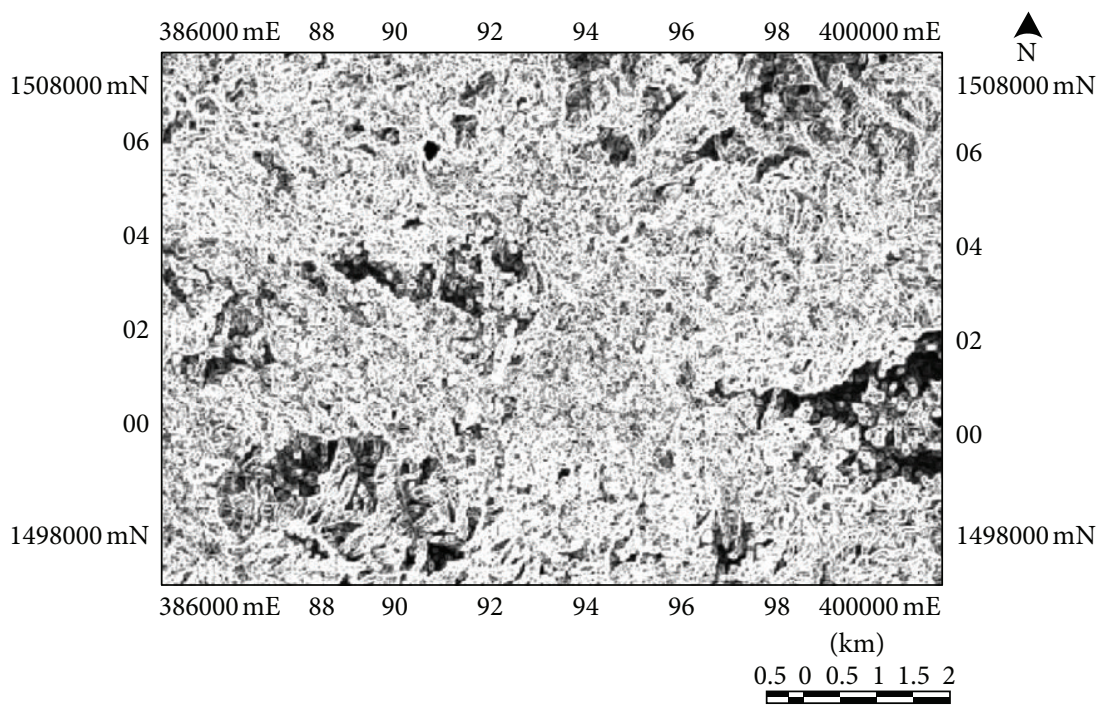

FIGURE 6: Threshold image produced by combining four filtered images.

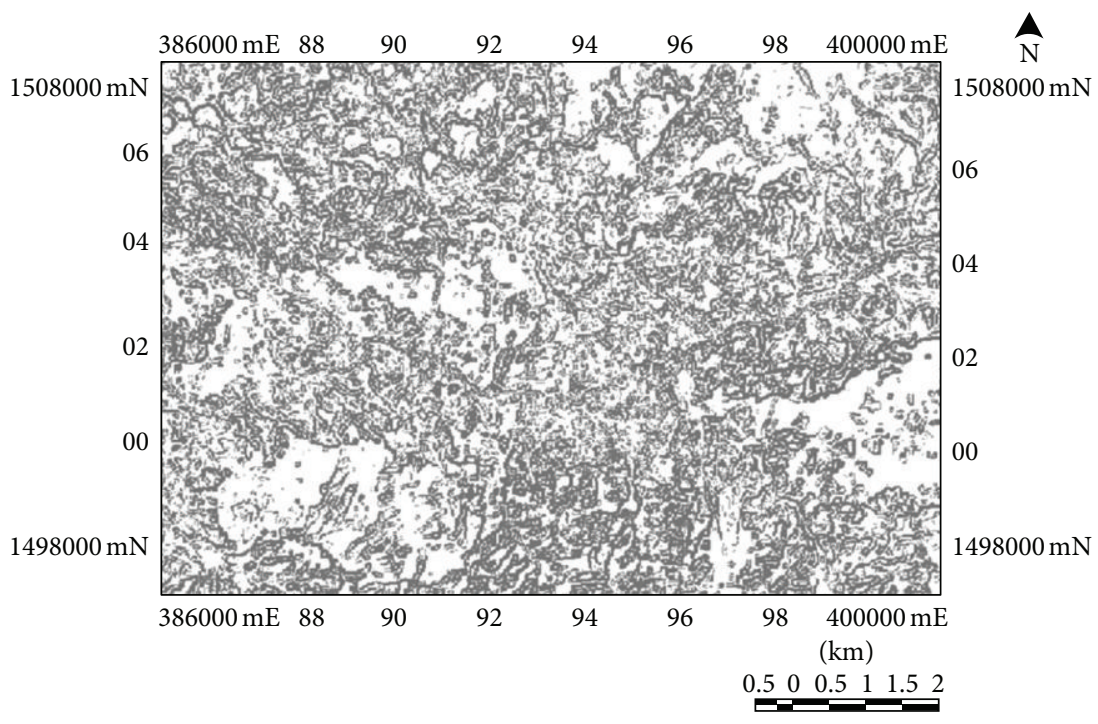

FIGURE 7: Binary image produced by using sobel filters.

TABLE 2: Sobel kernel filters in four main directions.

\begin{tabular}{cccccccccccc}
\hline & \multicolumn{10}{c}{ Four main principal directions } \\
\multicolumn{1}{c}{ NW-SE } & \multicolumn{1}{c}{ E-W } & \multicolumn{3}{c}{ NW-SE } & \multicolumn{3}{c}{ N-S } \\
\hline-2 & -1 & 0 & -1 & -2 & -1 & 0 & 1 & 2 & 1 & 0 & -1 \\
-1 & 0 & 1 & 0 & 0 & 0 & -1 & 0 & 1 & 2 & 0 & -2 \\
0 & 1 & 2 & 1 & 2 & 1 & -2 & -1 & 0 & 1 & 0 & -1 \\
\hline
\end{tabular}

The sobel filter was the best which convolved over band-5 in four principal directions and the filtered image was added back to the original image. The sobel filters in four principal directions are given in Table 2.

Then, the four enhanced filtered images combined together to produce one threshold filtered image (Figure 6), and this image was converted to binary image by applying adaptive thresholding. This adaptive threshold used to create binary images is controlled by two parameters, and the suitable values of adaptive thresholding parameters are windows size of 3 , and this value is equal to thinning of pixels and the mean offset of 3 . The final binary image of the study area is shown in Figure 7.

The lineaments detected during the interpretation process were digitized directly on the image on the screen, and the final lineament map was recorded and stored in vector files (Figure 8).

There are important points which need to be mentioned and should be followed in relation to the above procedure for lineament mapping. First, care is needed in the interpretation of the result of such analysis to exclude man-made features; therefore, the final map was screened to remove lineaments related to cultural features such as roads, canals, and field 


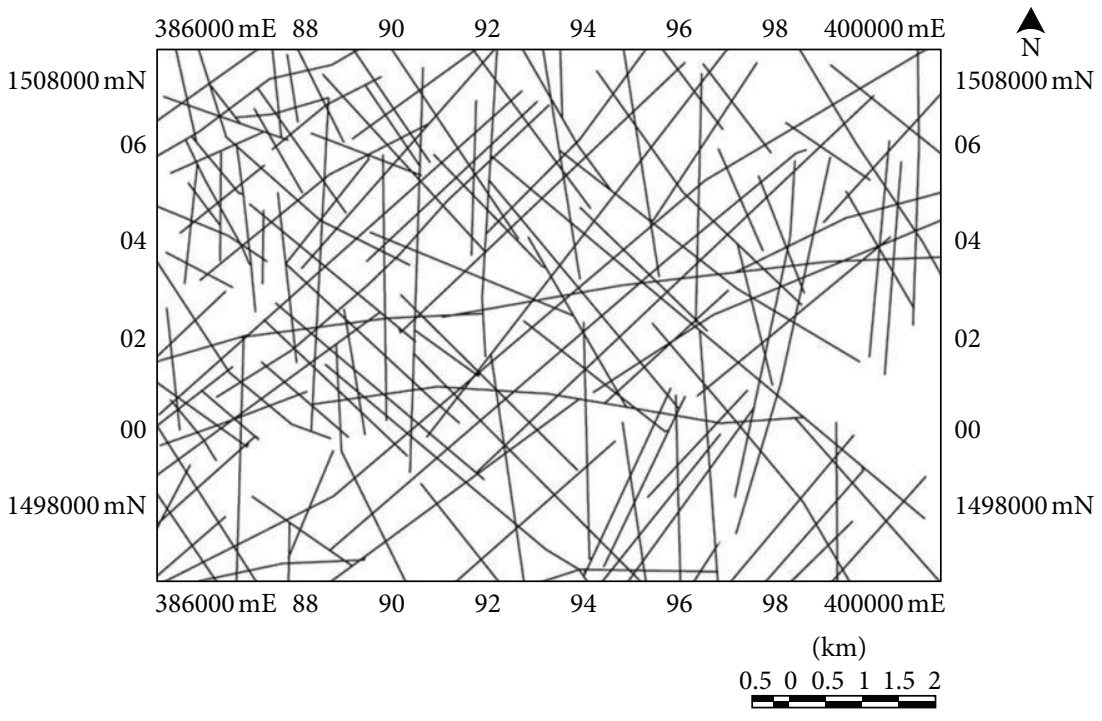

FIGURE 8: Lineaments extracted from binary image.

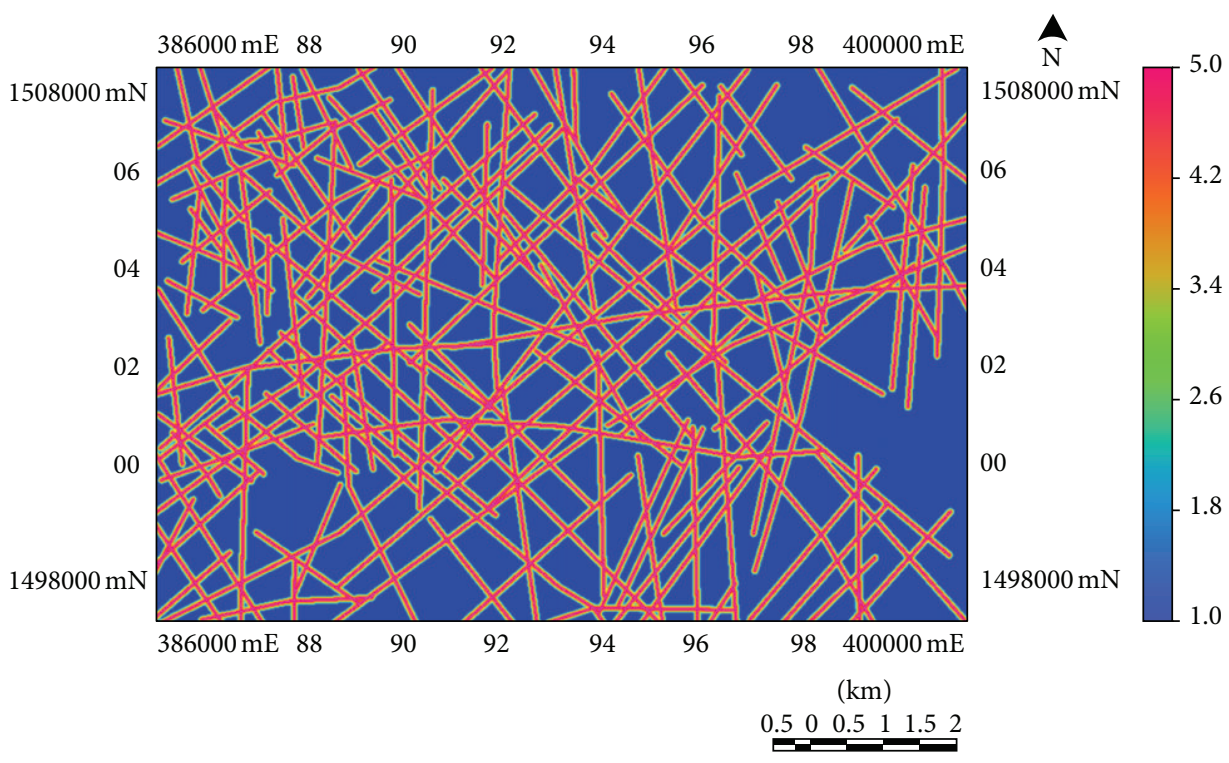

FIGURE 9: Lineament weight layer.

plantation boundaries by comparing it with the topographic maps and geological map of the area. All procedures mentioned above have been followed during trace lineaments from binary image.

The lineament map was prepared and converted into lineament buffer layer and then converted into slicing layer with five classes. Finally, this layer was converted into weights layer (Figure 9). The weight value was assigned to be between 1 and 5 (Table 2). And, this layer was ready to be input into GIS modeling.

2.1.2. Drainage Patterns Factor. The drainage pattern is apparently being controlled by structure and lithology in the study area. The lithologic variation has given a rise to different drainage patterns. For example, radial and dendritic drainage patterns are developed over granitic rocks. Moreover, the most important feature in the area is the presence of drainage lines patterns and fault lines. It is clearly to see that there is a good relationship between these fault lines and drainage pattern system distribution especially with third and fourth river orders in the area.

Geological features are any alignment of features on satellite images such as the various types recognized including topographic, drainage, vegetative, and color alignments. Digital elevation models (DEMs) are very useful in aiding the classification of landforms for many purposes such as recognition of drainage patterns. Extraction of topographic feature information from DEMs has become increasingly popular in structural analysis [40]. Digital elevation models (DEMs) data were used to trace tectonic features and 


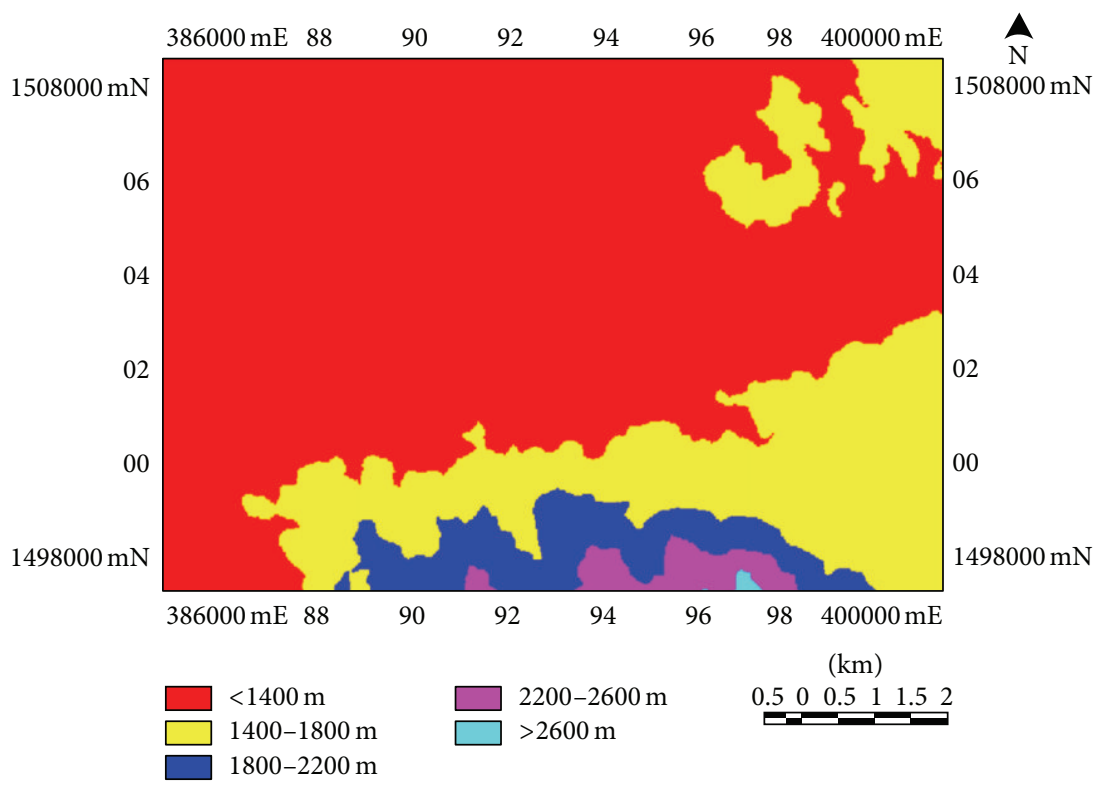

FIGURE 10: Digital elevation model (DEM) of the study area.

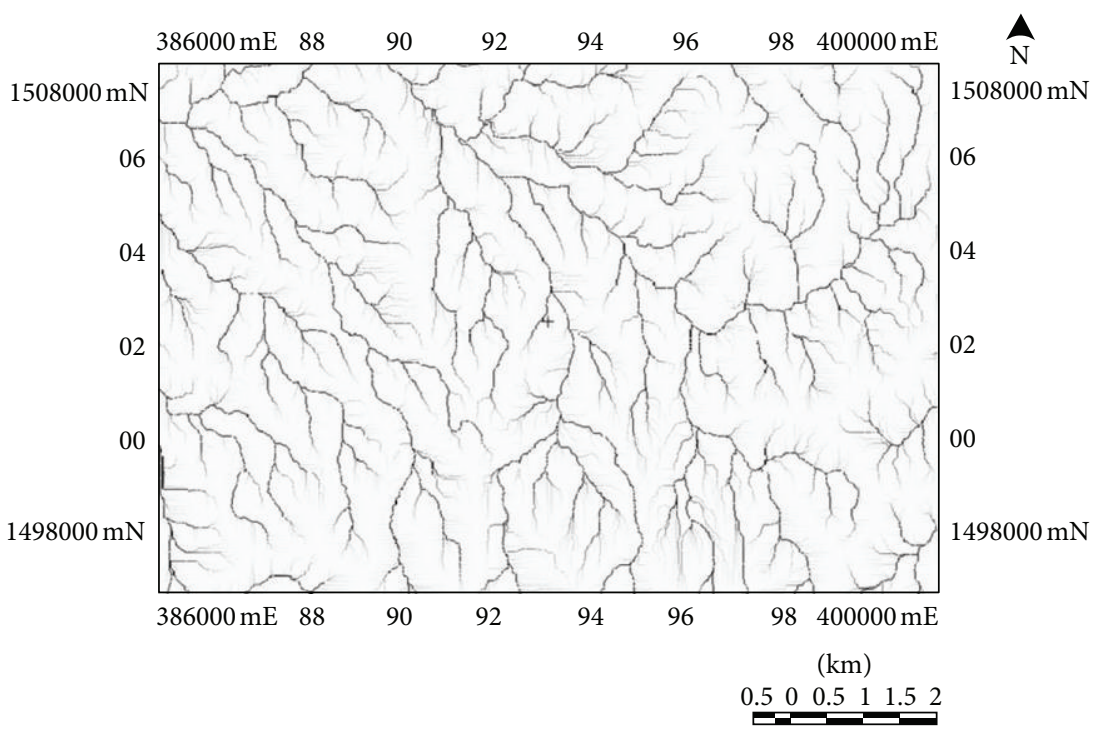

FIGURE 11: Drainage patterns map showing the nature of drainage system in the area.

mapping geologically and topographically defined structures in many areas [41]. The Shuttle Radar Topography Mission (SRTM) data were also used to trace drainage pattern system and mapping structures features [42]. The extraction of negative system lines (fault lines) from DEM data mostly resembles drainage lines patterns [43].

SRTM radar images with $90 \mathrm{~m}$ resolution were used to obtain contour line data. This contour data was used to create the DEM with $30 \mathrm{~m}$ resolution of the study area. The interpolation and resampling processing techniques were used to convert the contour line data (polygon) into $30 \mathrm{~m}$ grid layer and the grid layer was converted into a DEM with $30 \mathrm{~m}$ spatial resolutions (Figure 10).
This DEMs data was used for automatic extraction of drainage patterns over the study area using drainage basin from elevation data function (DRAIN) of PCI Geomatica software version 9.1. The drainage basin from elevation data function (DRAIN) locates the drainage networks (river or stream) within the DEM. The output data channel will appear as lines representing the rivers and streams [44].

The result of the drainage pattern map using automatic extraction technique is shown in Figure 11. This technique helps us to extract the drainage patterns over the settlement area, and the topographic maps were used as reference data.

This map was converted into vector layer. The drainage pattern layer (vector layer) was converted into drainage buffer 


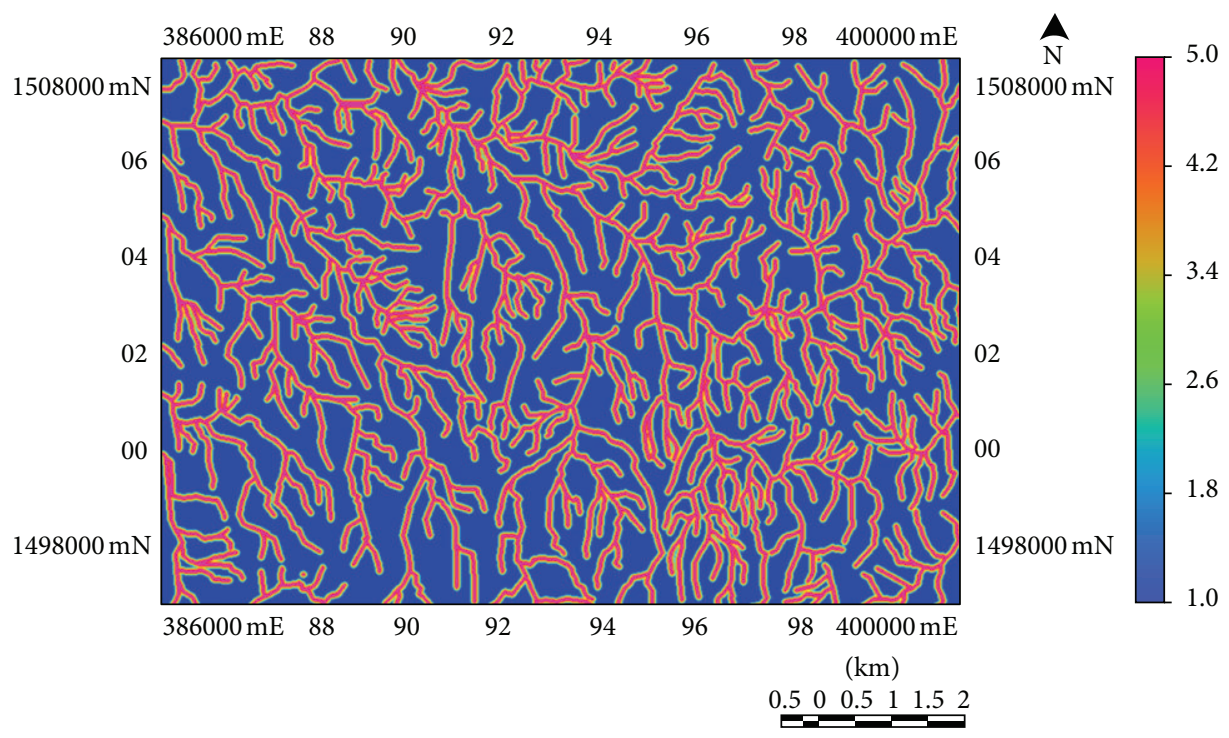

FIGURE 12: Drainage weight layer.

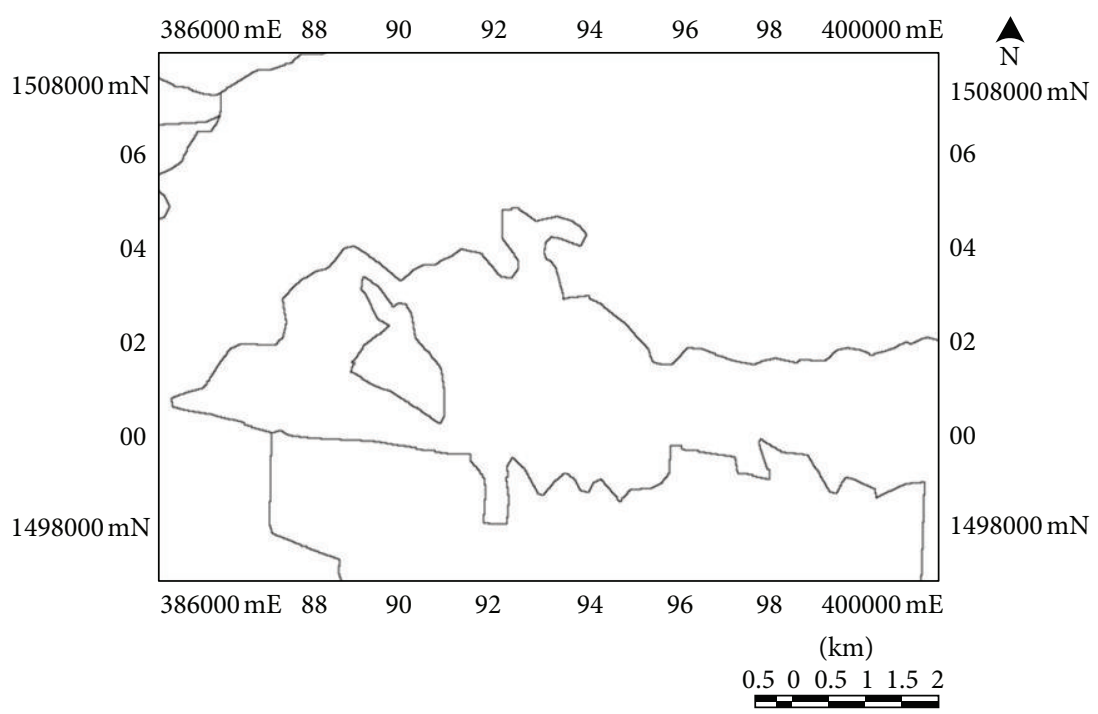

FIGURE 13: Lithological contacts layer [20].

layer and then converted into slicing layer with five classes. This map was converted into weights layer (Figure 12). The weight value was assigned to be between 1 and 5 (Table 1). This layer was ready to be input into GIS modeling.

2.1.3. Lithological Contact Factor. Lithological contacts were found in the field, such as bedding planes and lithological contacts between different rock types. The lithological contact layer of the study area (Figure 13) was digitized from the geological sheet map of Taiz with scale 1:250,000. The lithological contact layer (vector layer) was converted into lithological buffer layer and then converted into slicing layer with five classes. And this map was converted into weights layer (Figure 14). The weight value was assigned to be between
1 and 5 (Table 1). This map was ready to be input into GIS modeling.

2.1.4. Fault Factor. Geological structures are patterns such as faults, folds, joints, and others found in the rocks resulting from natural deformation [45]. The fault map of the study area (Figure 15) was digitized from the geological and the hydrogeological sheet maps of Taiz area with scales $1: 250,000$ and $1: 50,000$. The first sheet was prepared by geological survey of Yemen (GSY) and the second was prepared by National Water Resources Authority, Dar El-Yemen Hydro consultant [46]. This layer (fault layer) was converted into fault buffer layer and then converted into slicing layer with five classes. And this map was converted into weights layer (Figure 16). 


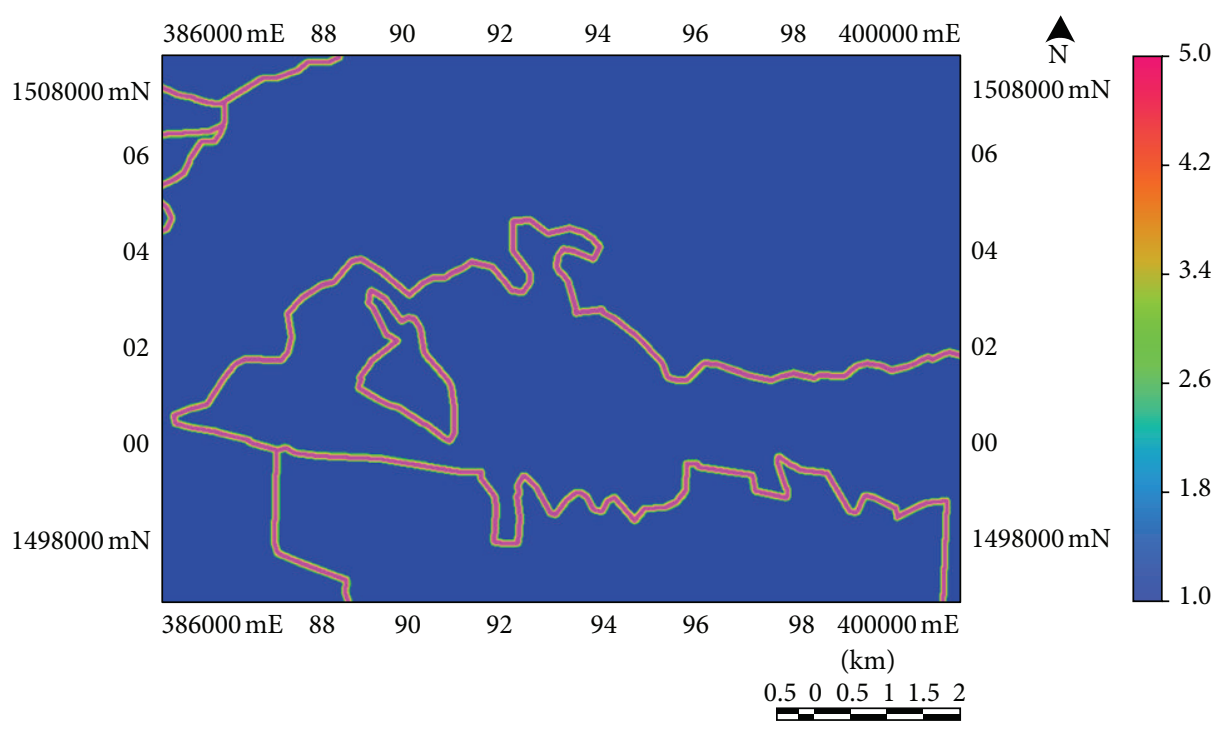

FIGURE 14: Lithological contacts weight layer.

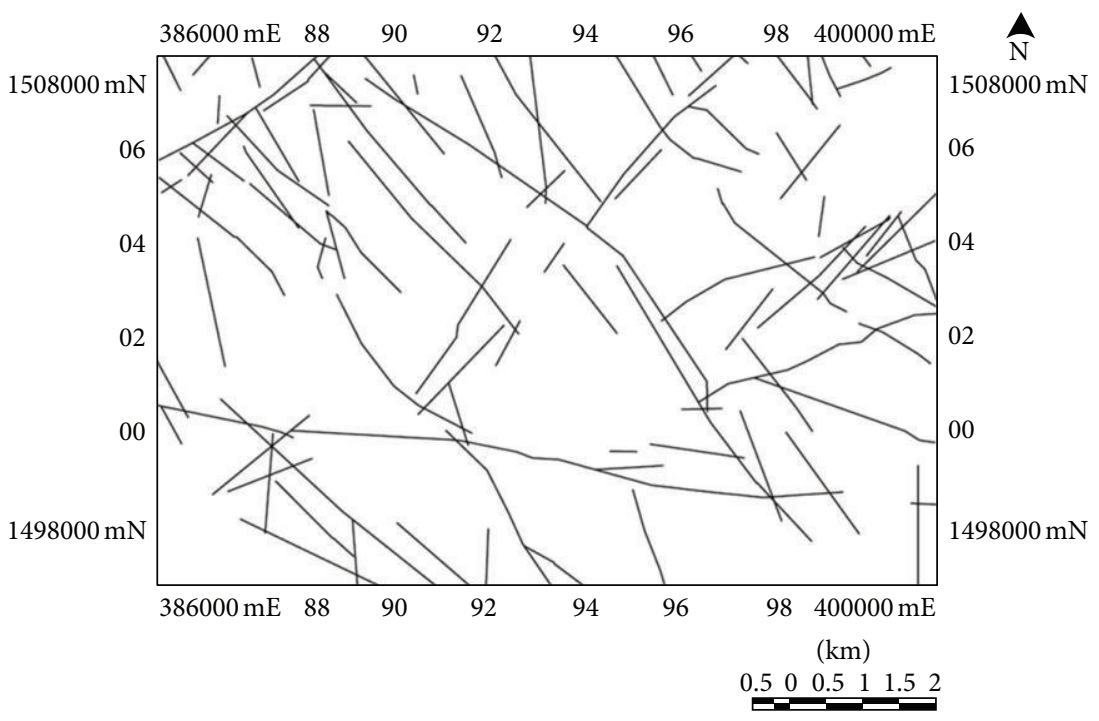

FIGURE 15: Fault map of the study area $[20,46]$.

The weight value was assigned to be between 1 and 5 (Table 1). This layer was ready to be input into GIS modeling.

2.2. GIS Model. The major goal of this study is to produce the fault susceptibility and the fault segment maps in order to get information about the possible locations of new faults existing in the area.

Generally, four digital weight layers such as drainage patterns, fault (previously mapped), lineament, and lithological contact layers were prepared from different data. The first step of the GIS modeling involves the input data (weight layers), and the second step includes selection of the suitable equation for this model to determine the susceptibility of faulting segments in the study area.

In this study, the overlay layers model (spatial multilayers analysis) was used preformed on these thematic maps with different weights by combining and aggregating these maps together with considering all different parameters. The fault susceptibility model produced with a modified linear equation of drastic model [47], using the following equation:

$$
\text { Potential Map }=\mathrm{DRN}_{\mathrm{W}}+\mathrm{FLT}_{\mathrm{W}}+\mathrm{LIN}_{\mathrm{W}}+\mathrm{GCT}_{\mathrm{W}},
$$

where, $\mathrm{DRN}_{\mathrm{W}}$ is the drainage weight layer, $\mathrm{FLT}_{\mathrm{W}}$ the fault weight layer (previously mapped), LIN $_{\mathrm{W}}$ the weight layer, and $\mathrm{LCT}_{\mathrm{W}}$ the lithological contact weight layer.

Researchers such as [48-50] classified the susceptibility into five potential classes, very low (VL), low (L), medium $(\mathrm{M})$, high $(\mathrm{H})$, and very high $(\mathrm{VH})$.

The resultant map (susceptibility map) was classified into different zones, including very low, low, moderate, high, and very high fault susceptibility zones or equal area classes using ranking values. 


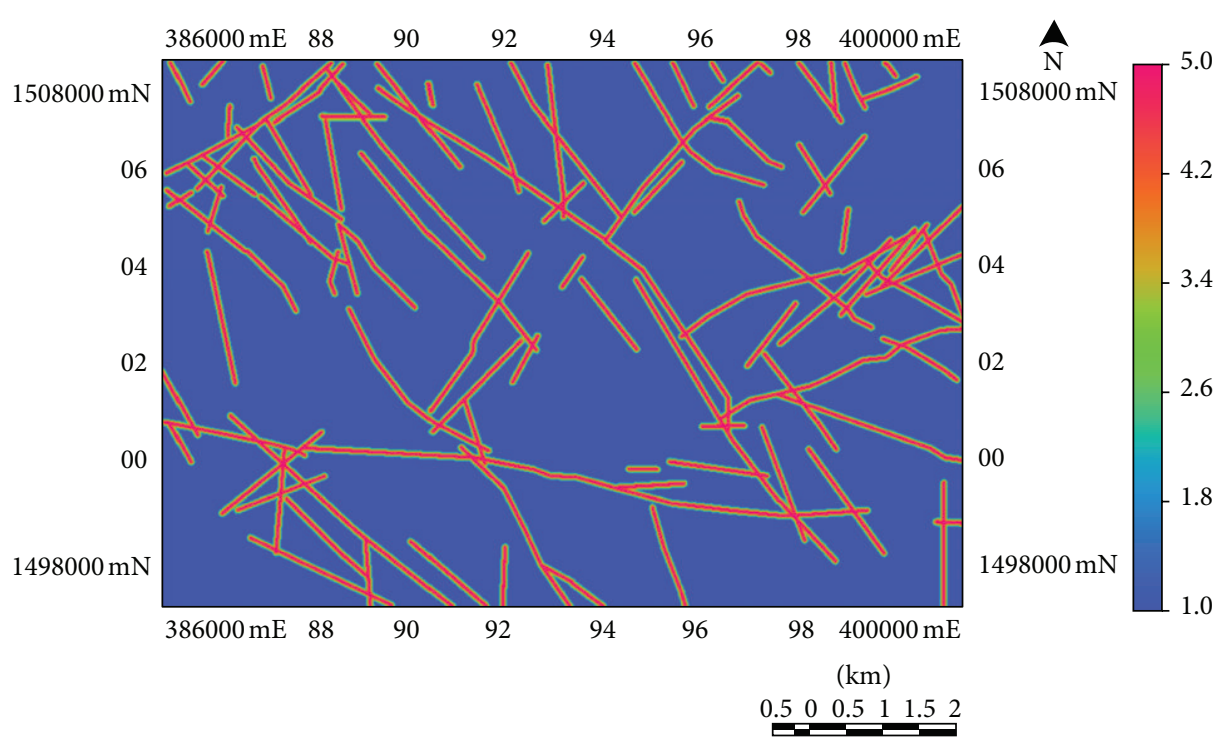

FIGURE 16: Fault weight layer.

2.3. Evaluation of the Susceptibility Map. The above-mentioned technique was used to produce the fault segment susceptibility map from the different data. The result obtained from this technique needs to be evaluated in some manner. The first evaluation was made with respect to the fault map (previous fault map) using GIS overlay technique to determine where the fault segments and true faults are matched over the study area.

During fieldwork, structural data (strike/dip of faults) were collected from 75 stations in the study area. These data were used for the fault segment map evaluation. These stations were located in the fault segments map to make whether there is any correlation between the fault segments and the faults collected from the field.

\section{Results and Discussion}

The final susceptibility map of faulting (potential fault zones) was produced as a result of the integration of all parameters of weight layers (drainage, fault (previously mapped), lineament, and lithological contact). This map was classified into five zones, namely, very low potential zone (VL), low potential zone (L), medium potential zone $(\mathrm{M})$, high potential zone $(\mathrm{H})$, and very high potential zone $(\mathrm{VH})$, as shown in Figure 17.

The potential zones in the fault susceptibility map show that the very low potential zone has a total area of $22.87 \%$, and the low potential zone has a total area of $51.89 \%$. More than half of the study area are dominated by very low and low potential zones. And this area does not reflect faults (faults in the previous map), while the $22.40 \%$ of moderate, $2.73 \%$ of high, and $0.11 \%$ of very high potential zones areas almost cover all the faults.

The evaluation of the susceptibility map has been computed by using GIS overlay capability techniques with the fault map of the study area to determine where the potential zones and faults are matched. In order to evaluate our susceptibility map for faulting, a comparison with the known structural fault lines has been done. The result of this technique shows that all of the faults were matched with the moderate to high and very high potential zones (continuous areas from moderate to high and very high).

There were some of moderate to high and very high potential areas in the susceptibility map that could not match any fault lines in the output map of the fault map. These fault segments identified by this technique may be surface reflections of the new fault locations in the study area which were not identified by previous works. This means that the use of this applied model worked successfully to identify linear features (e.g., fault lines) in the area of interest. The results suggest an additional 75 of new fault segment lines, which were not recognized by the fault map over the study area (Figure 18).

Moreover, the fault segments obtained from this model were shorter in length compared with faults that were observed in the field. For this reason, this paper attempted to determine the accuracy of this technique for fault segments mapping and the relationship between these segments and ground truth (faults) in terms of the length and the spatial distribution in the study area.

Based on the pattern of fault segments including the length, spatial distributions, and visual interpretation with a topographic map, a drainage pattern map, and three dimensions of DEM and Landsat ETM, the true length of fault segments could be recognized from this analysis and could be implemented in order to assess the extraction accuracy of every true fault length in the area.

Validation of result was made with the geological truth (field work) in the study area. During fieldwork, many faults were identified in different field work outcrops. Strike/dip readings of faults have been collected during the field work from different rock outcrops in the area. Based on the field data, these linear features identified on Landsat imagery and DEM are interpreted to be faults (Figure 19). 


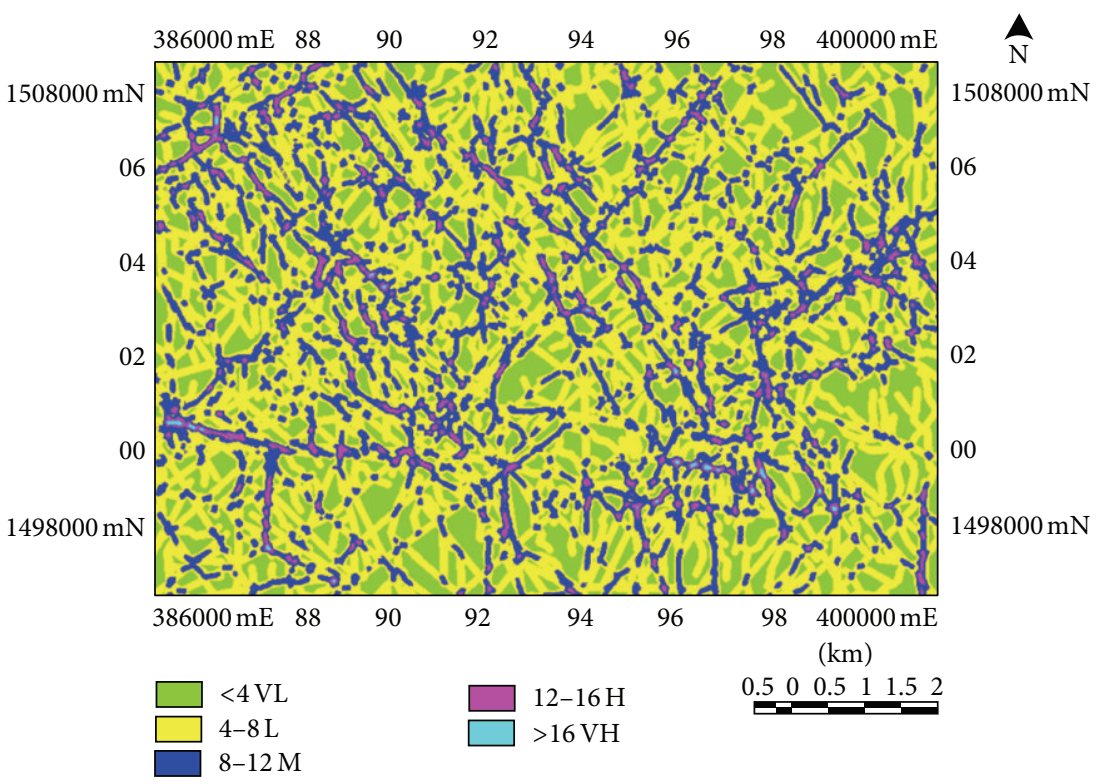

FIGURE 17: Susceptibility map of fault zones over the study area, classified into five zones, namely, very low potential zone (green), low potential zone (yellow), medium potential zone (blue), high potential zone (pink), and very high potential zone (cyan).

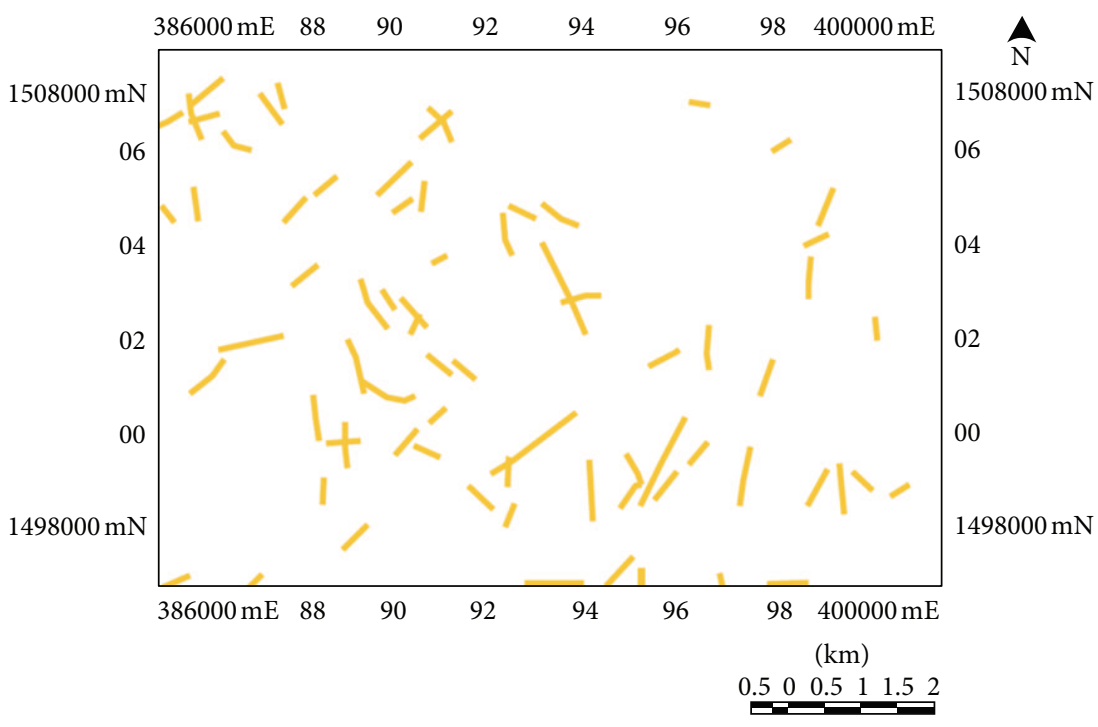

FIGURE 18: The 75 fault segments (faults lines) as a vector layer extracted from the susceptibility map over the study area.

The fieldwork stations were located in the fault segments map to make whether there is any correlation between the fault segments (faults lines identified by this technique) and the faults data collected from field work stations. There was good correlation between a few fault segments lines and faults, where 39 locations came in the same or nearby the location of fault segments (faults lines). Therefore, these 39 fault segments (faults lines) were identified as new faults (Figure 19). The structural reading (strike/dip) of faults from 93 fieldwork stations are given in Table 3.

Three fault systems were identified. These are the E-W, NW-SE, and NE-SW fault systems [46]. The area was subjected to intensive tectonic activity which resulted in a series of grabens, horsts, and tilted fault blocks. The tectonic activity deformed the area before the Tertiary volcanic activity, especially through the NE-SW faults which run parallel to the rift system of the Gulf of Aden, and it is considered the oldest fractures in the area. The NW-SE faults are run parallel to the opening of the Red Sea and occurred in the area during the Tertiary volcanic activity. The N-S and E-W fault system are the youngest major faults in the area. Smaller faults (as well as joints) also follow the same trends as the major faults. However, more intensive faulting is in the NW-SF direction [46].

Conjugate faults completely defined the principal stress direction. Strike and dip of the faults were plotted in equal-area projection of Schmidt net to obtain and calculate 
TABLE 3: Structure reading of faults from the field.

\begin{tabular}{lcccccccc}
\hline Location & North & East & Strike/dip & Name of fault & Location & North & East & Name of fault \\
\hline 1 & 1506721 & 387493 & N224E $/ 43^{\circ}$ & Normal & 21 & 1504706 & 392729 & Normal \\
2 & 1505753 & 387024 & N223E $/ 56^{\circ}$ & Normal & 22 & 1504886 & 392998 & Normal \\
3 & 1507429 & 386266 & N308E $/ 78^{\circ}$ & Reverse & 23 & 1502642 & 386915 & Reverse \\
4 & 1503679 & 386486 & N311E $/ 6^{\circ}$ & Reverse & 24 & 1501106 & 385718 & Reverse \\
5 & 1505813 & 389149 & N312E $/ 79^{\circ}$ & Reverse & 25 & 1499311 & 395042 & Shear \\
6 & 1500837 & 396967 & N329E $/ 58^{\circ}$ & Shear & 26 & 1500278 & 390156 & Reverse \\
7 & 1503011 & 398523 & N184E $/ 93^{\circ}$ & Shear & 27 & 1500228 & 392968 & Reverse \\
8 & 1505863 & 390066 & N313E $/ 96^{\circ}$ & Reverse & 28 & 1503100 & 393357 & Normal \\
9 & 1499101 & 398982 & N4E $/ 12^{\circ}$ & Shear & 29 & 1502003 & 388032 & Normal \\
10 & 1507229 & 390136 & N228E $/ 66^{\circ}$ & Normal & 30 & 1505354 & 390315 & Shear \\
11 & 1505334 & 389717 & N315E $/ 8^{\circ}$ & Reverse & 31 & 1502412 & 388301 & Shear \\
12 & 1506551 & 390625 & N15E $/ 65^{\circ}$ & Normal & 32 & 1499999 & 393786 & Shear \\
13 & 1502303 & 389926 & N219E $/ 45^{\circ}$ & Normal & 33 & 1500358 & 393906 & Shear \\
14 & 1501624 & 390674 & N225E $/ 15^{\circ}$ & Normal & 34 & 1502293 & 394434 & Shear \\
15 & 1500837 & 391781 & N226E $/ 11^{\circ}$ & Normal & 35 & 1498832 & 398294 & Reverse \\
16 & 1502632 & 390305 & N227E $/ 24^{\circ}$ & Normal & 36 & 1503579 & 385947 & Shear \\
17 & 1504397 & 389448 & N305E $/ 18^{\circ}$ & Reverse & 37 & 1502143 & 387334 & Shear \\
18 & 1499061 & 397037 & N352E $/ 47^{\circ}$ & Shear & 38 & 1504347 & 398483 & Reverse \\
19 & 1501994 & 396239 & N360E $/ 50^{\circ}$ & Shear & 39 & 1505903 & 397376 & Reverse \\
20 & 1502861 & 389757 & N217E $/ 47^{\circ}$ & Normal & & &
\end{tabular}

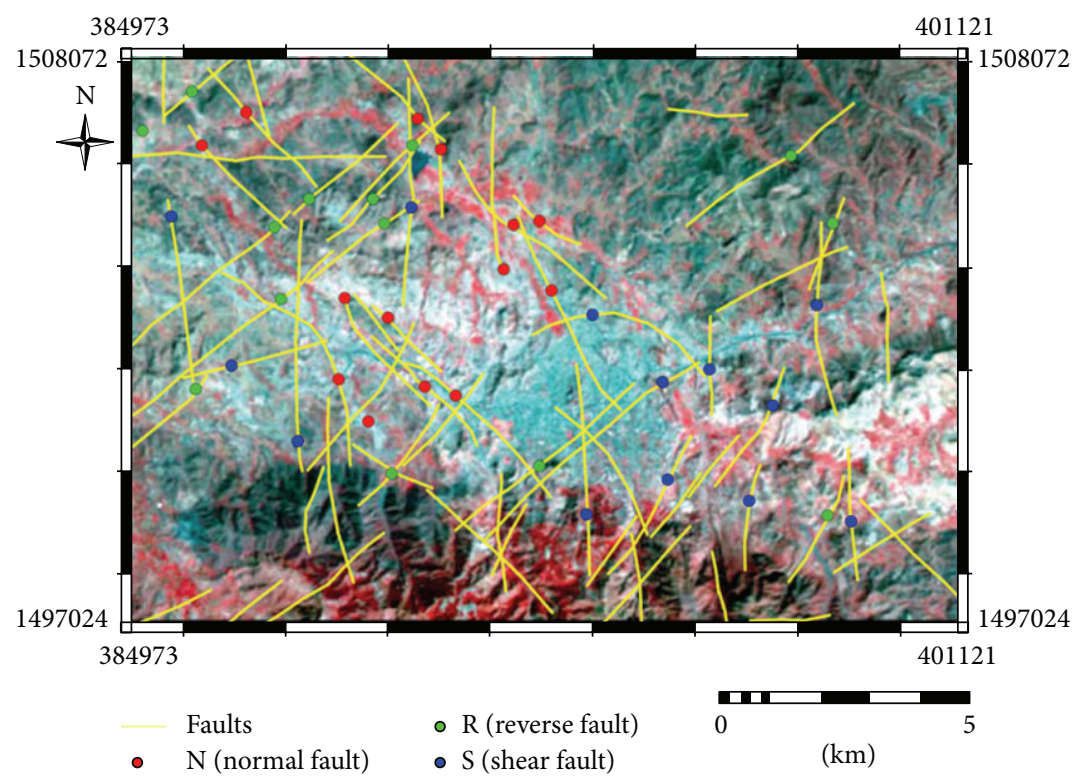

FIGURE 19: The 39 fault segments identified as faults in the study area showing true fault length and points of field work stations, normal fault segments indicated with red points, reverse fault segments indicated with green points, and strike slip fault segments indicated with blue points.

the directions of principal stresses which acted on those faults.

Totally 10 strike-dip readings of the conjugate faults from different rock units of the area were analyzed with the Stereonet program (Stero32 Version 0.9). The stereographic plot was prepared (Figure 20). According to the result of the conjugate faults analysis, compressional principal stress $(\sigma 1)$ is measured to be in the NE-SW direction.

This analysis indicates that the N-S and E-W orientated fault sets are sets of shear fractures which could be typical for strike slip faults. The NW-SE and NE-SW orientated sets are sets of tensional and extensional fractures, which could be 


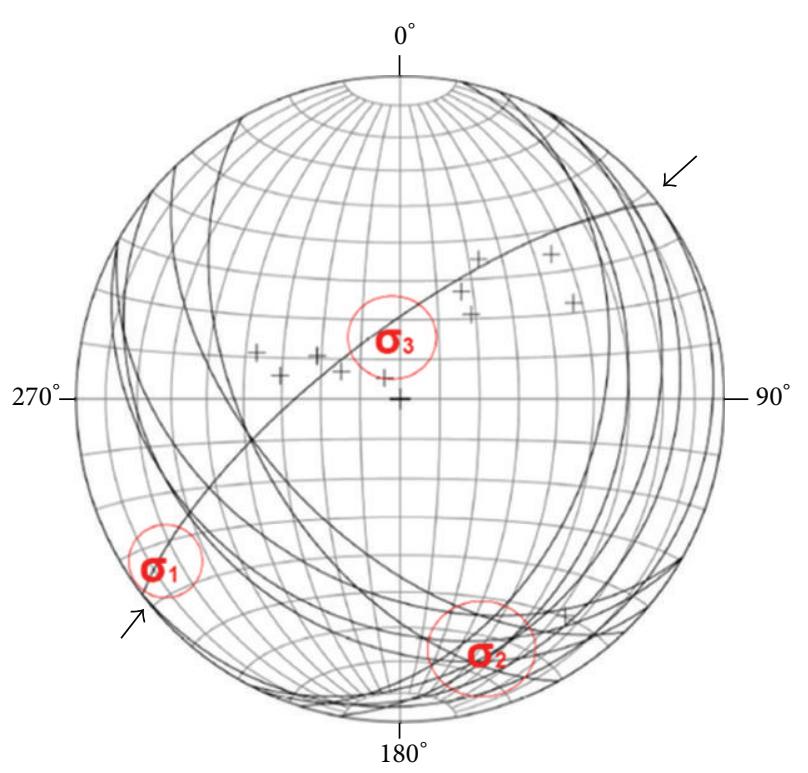

FIGURE 20: Result of conjugate faults using stereographic analysis.

typical for normal and reverse faults, respectively. Different field observations have also indicated that many damages were found or occurred along the NW-SE faults.

\section{Conclusions}

This study shows that remote sensing data and GIS technique are powerful tools in identifying geological structures such as fault segments in the urban area such as the Taiz city, Yemen. The use of different types of data such as drainage patterns, faults (previously mapped), lineament, and lithological contacts with spatial resolution of $30 \mathrm{~m}$ was combined through a process of integration and index overlay modeling technique for producing the susceptibility map (potential fault zones) of fault segments in the study area. GIS spatial overlay technique was used to determine the spatial relationships of all the criteria (factors) and subcriteria (classes) within layers (maps) to classify and map the potential area of fault zones of the study area. The fault segments map shows that there is good correlation and distribution between fault segments and faults (previous fault lines) in the study area. There are 39 fault segments which may represent new faults in the area being identified. The presence of these faults is not known from the literature. These faults could be active due to the rift system of the Gulf of Eden and opening Red Sea. Active or reactivated faults can cause enormous damage to settlement or urban (houses or construction project) areas by rock mass movement along the fault surfaces or bedrock cracks, damage which refers to loss of life or injury, or damage to roads. Furthermore, geological survey of Yemen is requested to update the maps and create new ones using new data and techniques and advise the people about the proper sitting of houses and restricting settlement activities in danger areas. GIS models can then yield more accurate estimates of the fault mapping using more data such as geophysical data.

\section{Acknowledgment}

The authors would like to thank the Geology Department, Faculty of Applied Science, Taiz University, Taiz, Yemen for the support to this research and staff for their valuable helps and comments.

\section{References}

[1] B. Dehandschutter, Study of the structural evolution of continental basins in Altai, central Asia [Ph.D. thesis], 2001.

[2] W. H. Hobbs, "Lineaments of the Atlantic Border region," Geological Society, vol. 15, pp. 483-506, 1904.

[3] W. H. Hobbs, "Repeating patterns in the relief and in the structure of the land," Geological Society, vol. 22, pp. 123-176, 1911.

[4] L. E. Arlegui and M. A. Soriano, "Characterizing lineaments from satellite images and field studies in the central Ebro basin (NE Spain)," International Journal of Remote Sensing, vol. 19, no. 16, pp. 3169-3185, 1998.

[5] R. T. Walker, "A remote sensing study of active folding and faulting in southern Kerman province, southeast Iran," Journal of Structural Geology, vol. 28, no. 4, pp. 654-668, 2006.

[6] C. Travaglia and N. Dainelli, Groundwater Search by Remote Sensing: A Methodological Approach, Environment and Natural Resources, FAO, Rome, Italy, 2003.

[7] M. Morisawa, Rivers, Longman, New York, NY, USA, 1985.

[8] C. E. Brockmann, A. Fernandez, R. Ballon, and I. I. Claure, "Analysis of geological structures based on landsat-1 images," in Remote Sensing Applications for Mineral Exploration, W. L. Smith, Ed., pp. 292-317, Dowden, Hutchinson and Ross, Strondsberg, Pa, USA, 1977.

[9] P. T. Nguyen and D. Ho, "Multiple source data processing in remote sensing," in Digital Image Processing in Remote Sensing, J. P. Muller, Ed., pp. 153-176, Taylor and Francis, Philadelphia, $\mathrm{Pa}, \mathrm{USA}, 1988$.

[10] X. Chen, Application of remote sensing and GIS techniques for environmental geologic investigation, northeast Iowa [Ph.D. thesis], University of Iowa, Iowa, Iowa, USA, 1992.

[11] A. Ü. Akman and K. Tüfekçi, "Determination and characterization of fault systems and geomorphological features by RS and GIS techniques in the WSW part of Turkey," in Proceedings of the 20th ISPRS Congress, pp. 899-904, Istanbul, Turkey, 2004.

[12] P. R. E. Guerra, Faulting evidence of isostatic uplift in the rincon mountains metamorphic core complex, an image processing analysis [Ph.D. thesis], 2000.

[13] M. A. Juhari and A. Ibrahim, "Geological applications of Landsat TM imagery: mapping and analysis of lineaments in NW Peninsula Malaysia," in Proceedings of the 18th Asian Conference on Remote Sensing, pp. J-1-1-J-1-8, Kuala Lumpur, Malaysia, 1997.

[14] W. F. P. G. Micheal, "Lineaments analysis South Florida region, aquifer storage and recovery regional study," Draft Technical Memorandum, Central and Southren Florida Project, Army Corps of Engineers, Jacksonville, Fla, USA, 2004.

[15] I. D. Novak and N. Soulakellis, "Identifying geomorphic features using LANDSAT-5/TM data processing techniques on Lesvos, Greece," Geomorphology, vol. 34, no. 1-2, pp. 101-109, 2000.

[16] S. Solomon and W. Ghebreab, "Lineament characterization and their tectonic significance using Landsat TM data and field 
studies in the central highlands of Eritrea," Journal of African Earth Sciences, vol. 46, no. 4, pp. 371-378, 2006.

[17] K. S. Kavak and H. Cetin, "A detailed geologic lineament analysis using landsat TM data of Gölmarmara/Manisa region, Turkey," Online Journal of Earth Sciences, vol. 1, no. 3, pp. 145153, 2007.

[18] L. A. Rutty, The basement fracture pattern of sothern Ontario: a tectonic interpretation based on landsat TM imagery, airphotos and field data [M.S. thesis], National Library of Canada, Ottawa, Canada, 1993.

[19] K. M. M. Elias, "Multiple data set integration for structural and stratigraphic analysis of Oil and Gas bearing formation using GIS," in Proceedings of the Map India Conference, Geology \& Mineral Resource, 2003.

[20] Geological Survey of Yemen (GSY), Geological Map of Taiz Area (1:250, 000), 1990.

[21] S. Bai, J. Wang, G. N. Lu, P. G. Zhou, S. S. Hou, and S. N. $\mathrm{Xu}$, "GIS-based logistic regression for landslide susceptibility mapping of the zhongxian segment in the three gorges area, China," Geomorphology, vol. 115, pp. 23-31, 2010.

[22] R. L. Bates and J. A. Jackson, Glossary of Geology, American Geological Institute, Alexandria, Va, USA, 1987.

[23] M. L. Süzen and V. Doyuran, "Data driven bivariate landslide susceptibility assessment using geographical information systems: a method and application to Asarsuyu catchment, Turkey," Engineering Geology, vol. 71, no. 3-4, pp. 303-321, 2004.

[24] F. Guzzetti, A. Carrara, M. Cardinali, and P. Reichenbach, "Landslide hazard evaluation: a review of current techniques and their application in a multi-scale study, Central Italy," Geomorphology, vol. 31, no. 1-4, pp. 181-216, 1999.

[25] C. F. Chung and A. G. Fabbri, "Probabilistic prediction models for landslide hazard mapping," Photogrammetric Engineering and Remote Sensing, vol. 65, no. 12, pp. 1389-1399, 1999.

[26] F. C. Dai and C. F. Lee, "Landslide characteristics and slope instability modeling using GIS, Lantau Island, Hong Kong," Geomorphology, vol. 42, no. 3-4, pp. 213-228, 2002.

[27] L. Ayalew, H. Yamagishi, and N. Ugawa, "Landslide susceptibility mapping using GIS-based weighted linear combination, the case in Tsugawa area of Agano river, Niigata prefecture, Japan," Landslides, vol. 1, pp. 73-81, 2004.

[28] T. B. Minor, J. A. Carter, M. M. Chesley, and R. B. Knowles, "An integrated approach to groundwater exploration in developing countries using GIS and remote sensing," in Proceedings of the International American Congress on Surveying and Mapping/American Society for Photogrammetry and Remote Sensing (ACSM/ASPRS '94), pp. 418-428, 1994.

[29] S. Lee and K. Min, "Statistical analysis of landslide susceptibility at Yongin, Korea," Environmental Geology, vol. 40, no. 9, pp. 1095-1113, 2001.

[30] L. Donati and M. C. Turrini, "An objective method to rank the importance of the factors predisposing to landslides with the GIS methodology: application to an area of the Apennines (Valnerina, Perugia, Italy)," Engineering Geology, vol. 63, no. 34, pp. 277-289, 2002.

[31] A. Günther, "SLOPEMAP: programs for automated mapping of geometrical and kinematical properties of hard rock hill slopes," Computers and Geosciences, vol. 29, no. 7, pp. 865-875, 2003.

[32] S. A. Ali and S. Pirasteh, "Geological applications of Landsat Enhanced Thematic Mapper (ETM) data and Geographic Information System (GIS): mapping and structural interpretation in south-west Iran, Zagros Structural Belt," International Journal of Remote Sensing, vol. 25, no. 21, pp. 4715-4727, 2004.
[33] G. Jordan, B. M. L. Meijninger, D. J. J. V. Hinsbergen, J. E. Meulenkamp, and P. M. V. Dijk, "Extraction of morphotectonic features from DEMs: development and applications for study areas in Hungary and NW Greece," International Journal of Applied Earth Observation and Geoinformation, vol. 7, no. 3, pp. 163-182, 2005.

[34] A. Anwar, M. A. Juhari, and A. Ibrahim, "The extraction of lineaments using slope image derived from digital elevation model: case study of Sungai Lembing-Maran area, Malaysia," Journal of Applied Sciences Research, vol. 6, no. 11, pp. 1745-1751, 2010.

[35] K. Koike, S. Nagano, and M. Ohmi, "Lineament analysis of satellite images using a Segment Tracing Algorithm (STA)," Computers and Geosciences, vol. 21, no. 9, pp. 1091-1104, 1995.

[36] A. Mah, G. R. Taylor, P. Lennox, and L. Balia, "Lineament analysis of Landsat Thematic Mapper images, Northern Territory, Australia," Photogrammetric Engineering \& Remote Sensing, vol. 61, no. 6, pp. 761-773, 1995.

[37] A. Anwar, M. A. Juhari, and A. Ibrahim, "A comparison of landsat TM and SPOT data for lineament mapping in Hulu Lepar area, Pahang, Malaysia," European Journal of Scientific Research, vol. 34, no. 3, pp. 406-415, 2009.

[38] A. Masoud and K. Koike, “Tectonic architecture through Landsat-7 ETM+/SRTM DEM-derived lineaments and relationship to the hydrogeologic setting in Siwa region, NW Egypt," Journal of African Earth Sciences, vol. 45, no. 4-5, pp. 467-477, 2006.

[39] M. L. Süzen and V. Toprak, "Filtering of satellite images in geological lineament analyses: an application to a fault zone in Central Turkey,' International Journal of Remote Sensing, vol. 19, no. 6, pp. 1101-1114, 1998.

[40] A. Ganas, S. Pavlides, and V. Karastathis, "DEM-based morphometry of range-front escarpments in Attica, central Greece, and its relation to fault slip rates," Geomorphology, vol. 65, no. 3-4, pp. 301-319, 2005.

[41] S. Sarapirome, A. Surinkum, and P. Saksutthipong, "Application of DEM data to geological interpretation: Thong Pha Phum area, Thailand," in Proceedings of the 23rd Asian Conference on Remote Sensing (ACRS '02), Kathmandu, Nepal, 2002.

[42] G. Sarp and V. Toprak, "An Integrated Lineament Analysis from Satellite Images," in Proceedings of the 28th Asian Conference on Remote Sensing (ACRS '07), Kuala Lumpur, Malaysia, 2007.

[43] A. Anwar, M. A. Juhari, and A. Ibrahim, "Automatic mapping of lineaments using shaded relief images derived from digital elevation model (DEMs) in the Maran-Sungi Lembing area, Malaysia," Electronic Journal of Geotechnical Engineering, vol. 15, pp. 949-957, 2010.

[44] P. C. I. Geomatica, PCI Geomatica User's Guide Version 9. 1, Richmond Hill, Ontario, Canada, 2001.

[45] A. Ibrahim and M. A. Juhari, Dictionary of Geological the Basic Terms, Malaysia, National University of Malaysia, Selangor, Malaysia, 1990.

[46] National Water Resources Authority, Hydrogeologic Map of Taiz Area (1: 50, 000), Dar El-Yemen Hydro Consultant, 1997.

[47] L. Aller, T. Bennett, J. H. Lehr, and R. J. Petty, "DRASTIC: a standard system for evaluating groundwater pollution potential using hydrogeologic settings," Tech. Rep. EPA/600/2 85/018 R.S., Kerr Enviromental Research Laboratory, Enviromental Protection Agency, Ada, Okla, USA, 1995.

[48] M. J. Crozier, "Field Assessment of Slope Instability," in Slope Instability, D. Brunsden and D. Prior, Eds., pp. 103-142, John Wiley and Sons, New York, NY, USA, 1984. 
[49] Q. Zaruba and V. Mencl, Landslides and Their Control, Elsevier, Amsterdam, The Netherlands, 1982.

[50] I. Das, S. Sahoo, C. van Westen, A. Stein, and R. Hack, "Landslide susceptibility assessment using logistic regression and its comparison with a rock mass classification system, along a road section in the northern Himalayas (India)," Geomorphology, vol. 114 , no. 4, pp. 627-637, 2010. 

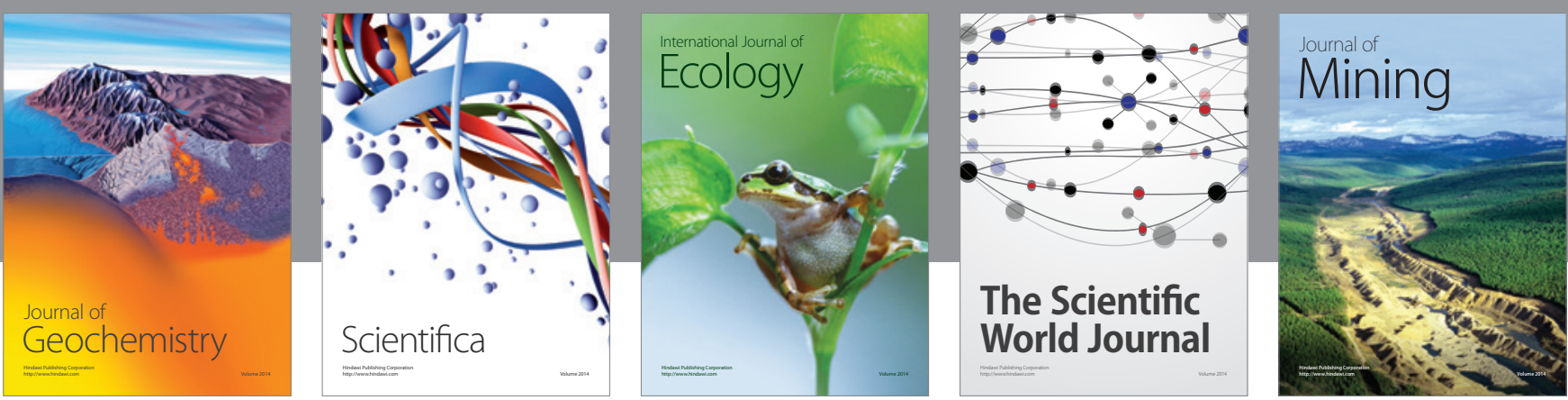

The Scientific World Journal
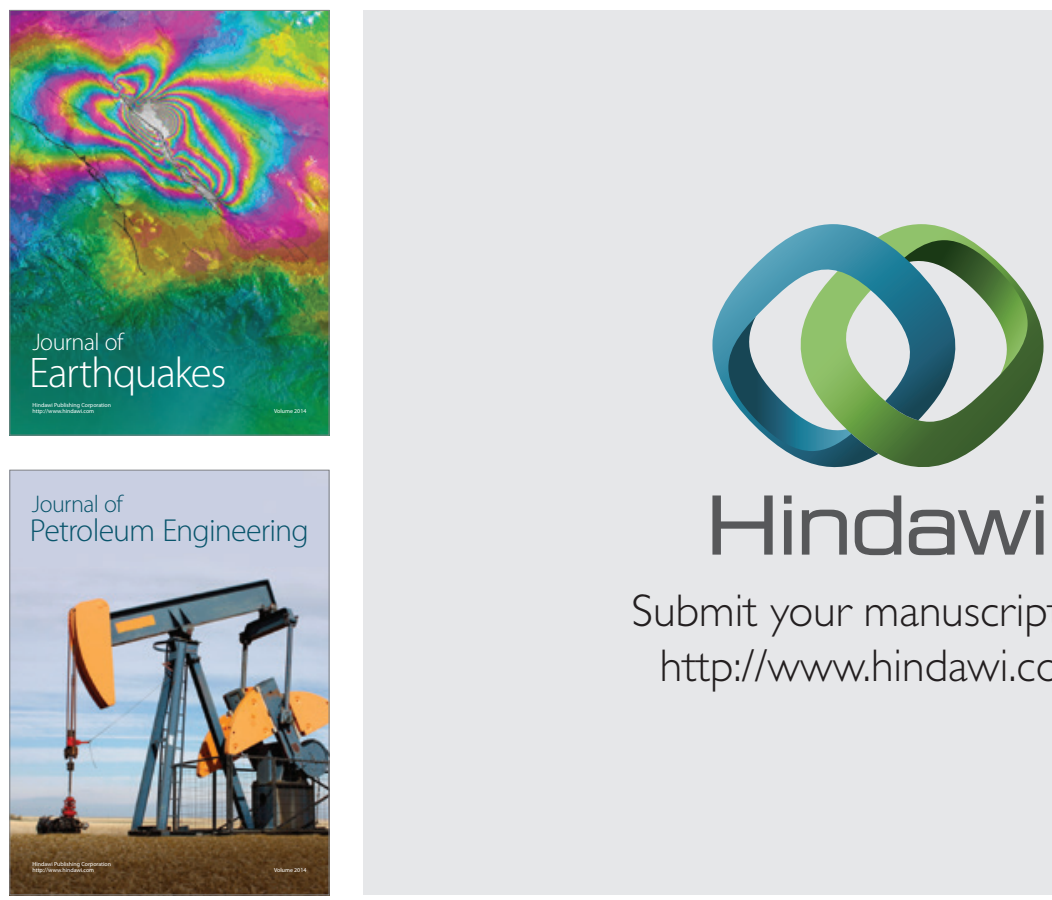

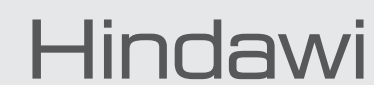

Submit your manuscripts at

http://www.hindawi.com
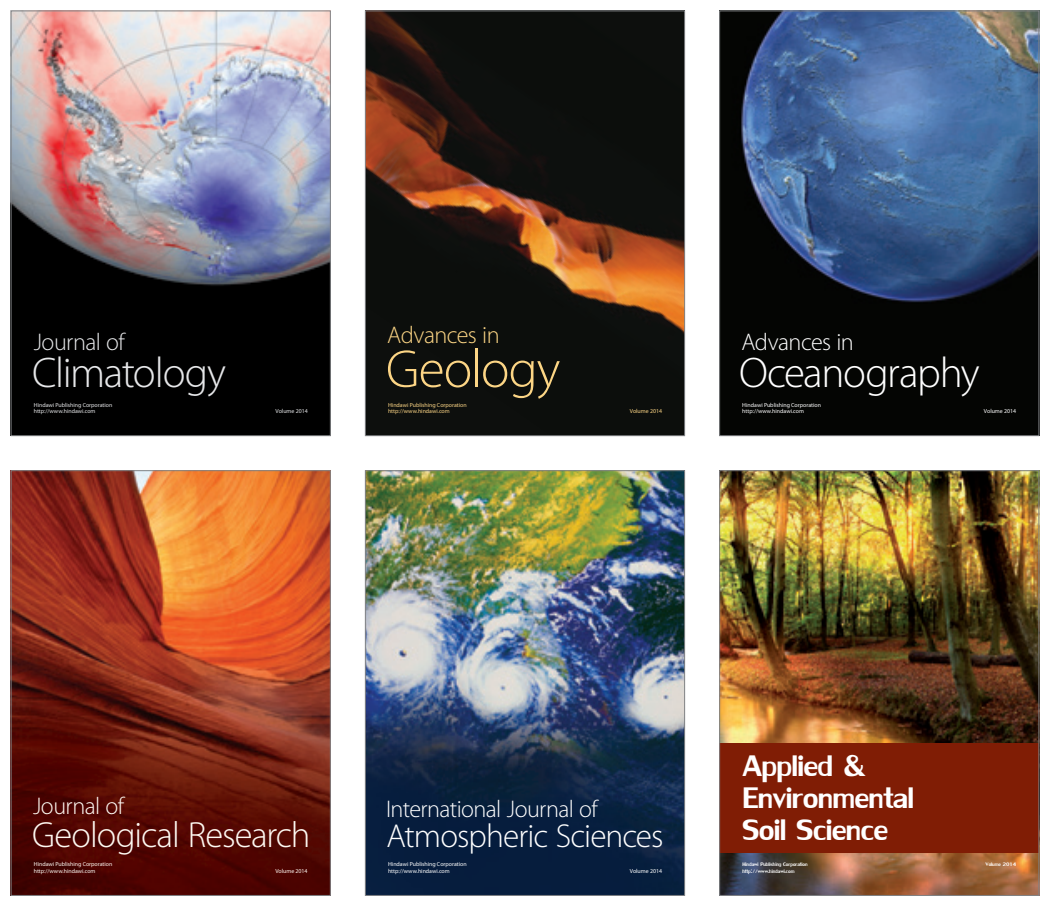
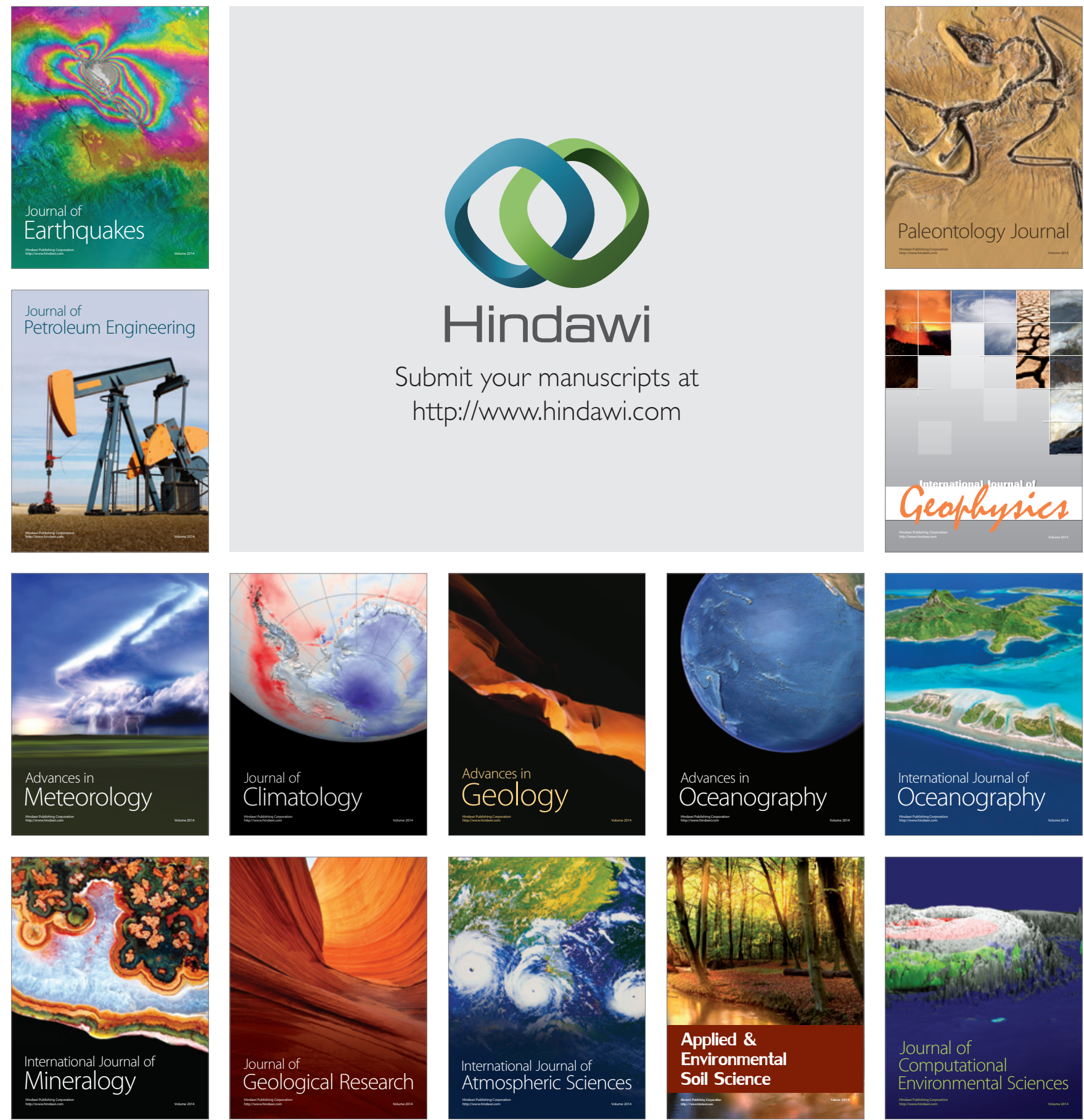